\title{
MODEL TREATMENT TERHADAP ANAK KORBAN VERBAL ABUSE DALAM KELUARGA
}

\author{
Moh. Usman \\ UIN Maulana Malik Ibrahim Malang \\ mohusmanainurrofiq@gmail.com
}

\begin{abstract}
This research is a literature review study regarding model of treatment of child victims of verbal abuse in the family. Verbal abuse is violence by using words. Most cases of verbal abuse against children are motivated by parents' ignorance of their effects, the experiences of parents who are also victims of verbal abuse, social culture, and the environment. Some of the effects of violence for children are that children will be permissive, depressive, aggressive, and also destructive. Especially because of verbal abuse, children can be a person who is inferior and insecure, even depressed. One model of treatment for child victims of verbal abuse is parents must approach children from heart to heart by apologizing and allowing their children to tell and talk. Let the emotions in the child's subconscious caused by verbal abuse disappear. Then the parents must show more affection, let the child do the work that feels capable of, give praise, and do not criticize the child. To maintain all, parents must be polite to children.
\end{abstract}

Keywords: Child, Violence in the family, Parents, Family Therapy, Verbal Abuse

\section{Abstrak}

Penelitian ini adalah penelitian literature review mengenai model treatment terhadap anak korban verbal abuse dalam keluarga. Verbal abuse merupakan kekerasan dengan memakai kata-kata. Kasus verbal abuse terhadap anak kebanyakan dilatar-belakangi oleh ketidaktahuan orang tua mengenai dampaknya, pengalaman orang tua yang juga menjadi korban verbal abuse, sosial budaya serta lingkungan. Beberapa dampak kekerasan bagi anak ialah anak akan bersikap permisif, depresif, agresif dan juga destruktif. Khusus sebab verbal abuse anak bisa menjadi pribadi yang minder dan tidak percaya diri, bahkan depresi. Salah satu model treatment terhadap anak korban verbal abuse adalah pertama orang tua harus melakukan pendekatan terhadap anak dari hati ke hati dengan meminta maaf dan membiarkan anaknya bercerita dan berbicara. Biarkan emosi-emosi dalam alam bawah sadar anak yang disebabkan oleh verbal abuse hilang terlebih dahulu. Kemudian orang tua harus lebih banyak menampilkan rasa kasih sayang, membiarkan anak melakukan pekerjaan yang dia rasa mampu, memberikan pujian dan jangan mengkritik anak. Untuk mempertahankan semua, orang tua harus bersikap santun terhadap anak.

Kata Kunci: Anak, Kekerasan dalam Keluarga, Orang Tua, Terapi Keluarga, Verbal Abuse 


\section{PENDAHULUAN}

Anak merupakan amanah dan juga karunia dari Allah Swt. yang benarbenar harus dijaga dan dididik karena dalam anak melekat tanggung jawab orang tua dan hak martabat sebagai insan yang harus dijunjung dan diimplementasikan. Oleh sebab itu, mendidik dan membesarkan anak sesuai dengan norma dan kepentingan terbaik bagi anak merupakan hak anak yang harus diberikan oleh orang tua (Purwanti, 2017).

Anak-anak di masa ini adalah orang dewasa di masa yang akan datang. Kelak mereka juga akan memiliki tanggung jawab sebagaimana orang dewasa saat ini. Bagaimana keadaan mereka di masa yang akan datang sangat tergantung dari perlakuan orang tua yang mereka terima saat ini (Basri, 1995). Di masa kanak-kanak, manusia ada dalam periode perkembangan individu dan pembentukan karakter. Sigmund Freud mengatakan bahwa lima tahun pertama dalam kehidupan manusia dapat menjadi faktor penentu kepribadiannya di masa depan. Mereka akan mengolah pengalaman yang didapat dalam hidupnya menjadi konsep diri. Periode ini juga dinamakan golden ages (Basri, 1995). Oleh karena apa yang akan diterimanya akan sangat berdampak pada perkembangan hidupnya, sudah seharusnya orang tuanya dapat memberikan hak-hak yang semestinya diperoleh seorang anak pada periode ini.

Daniel Golemen sebagaimana dikutip Abu Huraerah mengatakan bahwa ada beberapa langkah tidak efisien dalam mendidik anak, langkahlangkah tersebut hendaknya dihindari oleh orang tua, hal itu seperti mengabaikan perasaan anak, terlalu membebaskan anak, kemudian menghina dan tidak menunjukkan perasaan menghargai terhadap anak (Huraerah, 2018).

Jenis kekerasan terhadap anak dibagi menjadi berbagai macam, yakni: Pertama, kekerasan fisik. Kekerasan fisik merupakan kekerasan yang berdampak pada fisik. Seperti memukul, melukai, menjambak, mendorong dan sebagainya. Kedua, kekerasan seksual. Kekerasan seksual ialah kekerasan yang melibatkan anak dalam suatu aktivitas seksual yang mana hal itu tidak sepenuhnya dipahami, tidak disetujui atau anak belum siap untuk menerimanya. Kekerasan ini seperti meraba, mempertontonkan alat vital, memaksa anak dan mengancam untuk berhubungan asusila. Ketiga, kekerasan psikologis. Adapun kekerasan psikologis adalah kegagalan orang tua dalam memberikan pertumbuhan dan perkembangan yang baik terhadap anak, sehingga kompetensi sosial dan emosi yang ada dalam diri anak tidak stabil. Kekerasan macam ini dapat berakibat pada kondisi psikis anak, bahkan kesehatan fisiknya di masa depan, kemudian juga bisa berdampak 
pada perkembangan mental, moral spiritual dan sosial yang tidak baik. Kemudian yang terakhir ialah kekerasan sosial seperti penelantaran dan eksploitasi anak (Huraerah, 2018).

Sementara itu Terry E. Lawson mengatakan bahwa terdapat empat macam abuse yang biasanya dilakukan terhadap anak, yakni: Pertama, kekerasan secara fisik (physical abuse). Kedua, kekerasan emosional (emotional abuse). Adapun jenis kekerasan ini yakni di mana orang tua/pengasuh serta pelindung anak mengabaikan anak setelah tahu bahwa anaknya meginginkan perhatian. Kekerasan ini juga seperti ketika orang tua yang terlalu sibuk dengan pekerjaannya sehingga membiarkan anaknya kelaparan dan kebutuhannya terabaikan. Ketiga, kekerasan secara verbal (verbal abuse). Kekerasan secara verbal ialah kekerasan yang dilakukan dalam bentuk kata-kata, baik dengan menghina, menyudutkan, membandingbandingkan anak dan tindakan semacamnya. Keempat, kekerasan seksual (sexual abuse) (Kurniasari, 2019).

Masing-masing dari kekerasan di atas memiliki dampak yang tidak baik bagi anak. Namun di antaranya, kekerasan verbal atau verbal abuse-lah yang kekerasannya sangat sering dilakukan, tapi dampak psikologis yang akan dirasakan oleh anak tidak dipahami oleh orang tua. Beberapa orang tua bahkan menganggap bahwa kekerasan macam ini baik bagi perkembangan anak di masa depan. Inilah mengapa kebanyakan anak masih mengalami verbal abuse yang dilakukan oleh orang tuanya terhadapnya. Sebagaimana penelitian yang dilakukan oleh Novi Indrayati dan Livana PH terhadap 61 sampel anak mnghasilkan bahwa $86.9 \%$ atau sebanyak 53 anak mengalami verbal abuse, sedangkan $13.1 \%$ tidak mengalaminya (Indrayati \& Livana, 2019).

Oleh sebab itu kajian mengenai verbal abuse yang digalakkan tidak cukup hanya pada pengertian dan dampaknya, namun juga langkah-langkah yang harus dilakukan ketika mereka terlanjut melakukannya di masa lalu, maka di sini penulis menginisiasi untuk melakukan penelitian mengenai model treatment untuk membantu anak-anak korban verbal abuse dalam keluarga.

\section{METODE PENELITIAN}

Metode yang dilakukan dalam penelitian ini adalah literature review dengan mencari beberapa data melalui beberapa media. Tahap pencarian data dilakukan dengan menemukan banyak jurnal dan buku terkait dengan kata kunci kekerasan pada anak dan verbal abuse. Dari banyaknya artikel yang muncul hanya sebagian saja yang relevan. Jenis data dalam penelitian 
ini merupakan data sekunder yang didapat dari beberapa buku, jurnal dan dokumentasi lainnya. Data yang didapat lalu dianalisis dengan analisis deskriptif dengan memberikan penjelasan dan pemahaman secukupnya.

\section{HASIL PENELITIAN DAN PEMBAHASAN}

\section{Definisi Verbal Abuse}

Abuse adalah kata yang berarti kekerasan, penyiksaan serta penganiayaan. Child abuse atau child maltreatment sebagaimana dikutip Abu Huraerah adalah istilah bagi kekerasan yang terjadi pada anak (Huraerah, 2018).

Sementara verbal Abuse (kekerasan verbal) ialah kekerasan yang dilakukan terhadap seseorang dengan memakai kata-kata kasar, seperti memfitnah, menyudutkan orang lain, membesar-besarkan kesalahannya, menghina, mengancam, menakutkan, meneror, membentak, melampiaskan amarah. Verbal abuse yang dilakukan oleh orang tua pada anaknya terjadi sebab ketidakpahaman orang tua terhadap dampak dari verbal abuse, karena selama ini hal-hal yang semacam itu dianggap wajar. Kebanyakan dari orang tua menganggap bahwa dampak dari verbal abuse tidak begitu besar, terlebih jika dibandingkan dengan kekerasan fisik (Indrayati \& Livana, 2019).

Dalam pandangan Achmad Zuhrudin Verbal abuse terhadap anak ialah kekerasan yang dilakukan oleh orang tua kepada anak seperti dalam bentuk makian, celaan dan hinaan. Kekerasan ini kerapkali dianggap sebagai sutau hal yang biasa oleh orang tua, bahkan candaan. Padahal dampak yang terjadi terhadap anak ialah banyak, salah satunya adalah menyebabkan anak rendah diri dan meniru perlakukan kasar yang dialaminya (Zuhrudin, 2017).

Mengutip dari Dumas, Jean E. \& Wendy J. Nilsen, Zuhrudin menjelaskan beberapa contoh verbal abuse terhadap anak ialah: (1). Intimidasi, seperti mengancam, berteriak, menjerit dan menggertak anak. (2). Tidak sayang dan dingin seperti tidak menunjukkan rasa sayang sama sekali kepada anak. (3). Mempermalukan anak dan mengecilkannya seperti mencela, membandingkan, mengatakan bahwa si anak tidak ada harganya dan merendahkan. (4). Tidak mengindahkan anak atau menolaknya seperti dingin dan tidak memperhatikannya. (5). Selalu mencela anak sepeti selalu melempar kesalahan kepada anak. (6). Menghukum dengan ekstrim seperti mengikatnya di atas kursi, mengurungnya di suatu kamar gelap. (7). Melakukan eksploitasi kepada anak seperti mempekerjakannya untuk tujuan tertentu (8). Mengekspos kekerasan terhadap anak termasuk yang dilakukan oleh orang lain. (9). Menculik anak seperti membawa lari meskipun oleh orang tuanya sendiri (Zuhrudin, 2017). 
Kemudian sebagaimana dikutip oleh Asla De Vega, Hapidin dan Karnadi dari Loh Calleja dan Restubog, terdapat sembilan jenis verbal abuse yang kerapkali dilakukan orangtua pada anaknya yakni: melemparkan kesalahan atau mudah menyalahkan anak, melebih-lebihkan kesalahan, mengancam, sumpah serapah, membanding-bandingkan, merendahkan dan mempermalukan, prediksi negatif dan merendahkan (Vega, dkk, 2019).

\section{Faktor Terjadinya Verbal Abuse}

Sebagaimana dikutip dari Soetjiningsih terdapat beberapa faktor yang menjadikan orang tua melakukan verbal abuse terhadap anaknya yakni: (1). Pengatahuan orang tua: biasanya orang tua minim informasi mengenai dampak psikologis terhadap apa yang mereka lakukan dan katakan terhadap anaknya. (2). Pengalaman: orang tua yang melakukan kekerasna verbal terhadap anak biasanya mereka adalah korban dari kekerasan yang mereka alami. Sebab perlakukan yang dialami oleh anak-anak akan direkam dalam alam bawah sadar kemudian dibawa sampai dewasa. Apa yang mereka setelah lakukan saat dewasa bergantung pada apa yang diterimanya ketika kecil. (3). Keluarga: karekteristik orang tua dan karakteristik anak juga berperan terhadap adanya kekerasan verbal terhadap anak. (4). Ekonomi: Beban hidup kadang menjadikan orang tua lebih mudah marah dan emosi yang kadang kali diluapkan terhadap anak. (5). Sosial budaya: hal ini berkaitan dengan norma yang ada di masyarakat, pola hubungan antar manusianya, pendidikan, kesehatan dan sebagainya. Salah satu bentuknya adalah adanya anak berada di hierarki terbawah dalam pola hubungan dalam keluarga. (6). Lingkungan: faktor ini juga sangat berdampak pada verbal abuse orang tua terhadap anaknya. Hal ini seperti beban dalam merawat anak dan adanya masalah lingkungan yang muncul kadang juga menjadikan orang tua di luar kontrol dan bertindak semena-mena terhadap anak (Nazhifah, 2017).

Namun nampaknya ketidaktahuan orang tua mengenai verbal abuse dan dampaknya harus dikaji ulang. Hal ini karena terdapat penelitian dari Annora Mentari Putri dan Agus Santoso terhadap beberapa partisipan, hasil peneltian tersebut mengatakan bahwa meskipun para orang tua paham mengenai dampak verbal abuse namun terkadang para orang tua tetap melakukannya, seperti memarahi anak dan menjadikan anak pelampiasan kemarahan (Putri \& Santoso, 2012).

Salah satu bentuk verbal abuse ini adalah bullying. Sementara itu, mengenai bullying, ada beberapa faktor mengapa seseorang, baik anak-anak atau orang dewasa melakukannya, salah satunya yakni karena pelaku mudah 
putus asa, emosinya tidak terkendali, implusif dan seringkali menunjukkan kekerasan dalam berbagai cara (Sugijokanto, 2014). Suzie melanjutkan bahwa bullying atau bagian dari kekerasan verbal bisa terjadi karena dipengaruhi berbagai hal seperti pengaruh keluarga, pengaruh teknologi, baik medsos ataupun televisi, karena paksaan atau ajakan dari temantemannya, kemudian yang terakhir pernah menjadi korban bullying sebelumnya (Sugijokanto, 2014).

\section{Dampak Verbal Abuse Kepada Anak}

Dampak dari kekerasan (abuse) secara umum kepada anak bisa jadi ialah sebagai berikut: (a). Anak akan Bersikap permisif. Sikap ini ialah di mana anak merasa bahwa dirinya tak berguna dan tak bermanfaat. Oleh sebab itu mereka akan lebih banyak diam dan minder. Sehingga ke belakang mereka akan gagal dalam berhubungan dengan sekitarnya dan menjalin relasi antar sesama. (b). Anak akan bersikap depresif. Depresif di sini seperti anak yang selalu murung. Sebab ada masalah dalam alam bawah sadarnya ataupun dalam keadaan mereka yang sekarang sulit dihilangkan. Itulah mengapa mereka menjadi pendiam. Terkadang penakut terhadap sesuatu yang tidak jelas dan seringkali merasa cemas. (c). Anak akan Bersikap agresif. Contohnya seperti anak suka memberontak dan suka berprilaku buruk. Seperti merokok, minum dan menggunakan obat-obatan. Hal ini sebab mereka tidak bisa mengendalikan emosi buruk dalam dirinya. (d). Anak akan bersikap destruktif. Hal ini seperti ketika mereka ingin untuk menyakiti dirinya sendiri. kesal dan putus asa dalam dirinya terkadang juga menyebabkan mereka ingin melakukan bunuh diri. Biasanya semua berawal dari beban pikiran dan stress yang berkepanjangan (Kurniasari, 2019).

Kemudian pembahasan mengenai dampak dari verbal abuse nampaknya bukan pembahasan yang baru. Terdapat banyak kajian yang membuktikan bahwa memang kekerasan dalam bentuk kata-kata ini tidak baik bagi pertumbuhan anak. Padahal jenis kekerasan ini kerapkali dilakukan oleh orang tua dan meyakinkan bahwa hal itu baik bagi perkembangan anak.

Salah satu penelitian mengenai hal itu seperti penelitian dari Angle Mamesah, Sefti Rompas dan Mario Katuuk yang menyimpulkan bahwa terdapat hubungan antara verbal abuse yang dilakukan oleh orang tua dengan perkembangan kognitif anak. Semakin ringan bentuk verbal abuse maka dalam penelitian tersebut mengatakan perkembangan kognitif anak semakin sesuai atau baik. Tapi sebaliknya, semakin tinggi atau keras verbal abuse, maka perkembangan kognitif anak akan semakin kurang (Mamesah, 2018). 
Hal ini sebagaimana dinukil dari Fasli Jalal oleh Rohma (2018) bahwa ketika seorang anak dilahirkan, terdapat 100 Miliyar neutron di dalam otaknya yang saling bersambung selama masa tumbuh kembangnya di beberapa tahun pertama. Sel-sel dalam otak bayi tersebut kemudian berkembang menjadi triliunan sambungan sel. Kekuatan sambungan di antara sel inilah yang akan berpengaruh pada kecerdasan anak. Masa ini berlangsung selama 4 tahun sejak kelahiran anak. Di samping itu, penelitian juga mengungkapkan bahwa kecerdasan otak manusia $80 \%$ terbentuk pada usia anak ketika sampai 8 tahun.

Sedangkan dampak yang akan terjadi pada verbal abuse sebagaimana dalam penelitian Salami menukil dari Lise Gilot mengungkapkan bahwa dari triliunan sel otak dalam diri anak miliyaran diantaranya dapat musnah hanya dengan bentakan, makian dan perkataan kasar. Apabila disertai dengan cubitan, bisa jadi akan membunuh puluhan milyar sel-sel tersebut. Sebaliknya, pujian dan pelukan akan mengembangkan sel-sel tersebut. efek jangka panjang yang akan terjadi pada bentakan akan memberikan dampak jangka panjang kepada anak, semisal di waktu dewasa dia akan banyak melamun, lambat dalam memahami sesuatu, mudah meluapkan rasa marah dan sebagainya (Salami, 2015).

Vega, dkk (2019) juga melakukan penelitian yang menyimpulkan bahwa verbal abuse berpengaruh negatif terhadap kepercayaan diri anak dengan nilai korelasi 0,42 dan koefisien jalur sebesar -0,319. Kemudian juga mengutip dari penelitian Sari bahwa verbal abuse berdampak pada anak yang akan merasa minder di masa depan, rendah diri, tidak begitu percaya diri dan kecenderungan menutup diri dari sosialisasi. Meskipun tidak dapat dipungkiri verbal abuse juga dapat memicu semangat dan motivasi seorang anak (Sari, 2018).

\section{Metode Treatment Terhadap Anak Korban Verbal Abuse dalam Keluarga}

Menjadi orang tua berarti harus memikul tanggung jawab terhadap anak. Orang tua harus mampu mendidik, memberi kasih sayang dan membesarkan anak menjadi pribadi yang memiliki moral dan spirit yang baik, cerdas dan sehat secara rohani dan jasmani. Oleh sebab itu tugas sebagai orang tua menjadi full-time atau sepanjang waktu (Sugijokanto, 2014).

Hal yang perlu disadari oleh orang tua terlebih dahulu yakni bahwa anak merupakan bintang di bidangnya masing-masing. Ketika seorang anak tidak mampu di suatu bidang, maka orang tua harus yakni bahwa anak akan 
menguasai atau terampil di bidang lainnya. Hal ini perlu dipahami sebab terkadang kekerasan verbal terjadi karena orang tua yang terlalu perfeksionis dan menginginkan anak mahir dan cakap dalam segala bidang (Mahmud, 2019).

Salah satu dampak jangka pendek dalam verbal abuse adalah anak akan menjadi depresi. Beberapa ciri bahwa anak mengalami depresi yakni: sedih (anak merasa tidak bahagia selama beberapa minggu), menarik diri dari keluarga dan teman-temannya, terdapat perubahan pola tidur dan pola makan, mudah merasa diganggu, kerapkali kencing di celana, memiliki konsentrasi yang buruk, merasa bahwa dirinya tidak berharga, sering merasa marah dan benci terhadap orang lain dan terjadap punya keinginan untuk bunuh diri (Santosa, 2019).

Bisa jadi anak yang depresi karena suatu hal akan menyembunyikan permasalahannya dan akan tampil selayaknya sosok pemberani yang agresif. Langkah yang harus dilakukan adalah jangan terjebak dalam tingkah seharihari, mulai mendengarkan apa saja permasalahan anak dan berusaha lebih dekat dan terbuka dengannya. Kemudin hindari untuk membuat komentar seperti "itu konyol". Kemudian setelah semakin dekat, hendaknya orang tua bersiap untuk mengatakan secara bercanda apa yang kira-kira memalukan bagi anak, ini dapat membantu menghilangkan topeng buatan yang mereka simpan karena luka lama. Kemudian orang tua selayaknya harus melindungi anaknya dari anggota keluarga atau orang lain yang tidak baik cara bertutur kata pada anaknya (Santosa, 2019).

Dalam memberikan treatment terhadap anak yang menjadi korban kekerasan verbal, langkah petama yang harus dilakukan adalah memberikan peluang kepada anak untuk bercerita dan berbicara sebanyak mungkin mengenai apa yang tidak disukainya. Orang tua harus bersabar jika anak dirasa belum siap untuk berbicara. Orang tua yang sadar bahwa yang dilakukannya salah hendaknya meminta maaf dari hati terdalam kepada anak. Bila anak sudah berani berbicara, peluklah anak sebagai bentuk ketulusan dari permintaan maaf orang tua kepadanya. Kemudian berikan kesempatan pada anak untuk menyalurkan emosi-emosinya yang terpendam. Hal ini bermanfaat agar alam bawah sadarnya bisa mereduksi dampakdampak dari kekerasan verbal yang dialaminya di masa lalu (Sugijokanto, 2014).

Setelah kotoran mengenai dampak verbal abuse anak dalam alam bawah sadarnya mulai tereduksi, seyogyanya orang tua harus membangun kembali prilaku-prilaku anak yang diakibatkan oleh kekerasan verbal yang dialaminya. Muzdalifah memaparkan bahwa terdapat beberapa hal yang bisa 
dilakukan dalam membangun karakter anak yang percaya diri dan tidak minder, yakni: jangan ragu untuk menampilkan kepedulian dan penghargaan, membiarkan anak melakukan pekerjaan yang dia rasa mampu, memberikan pujian dan jangan mengkritik atau menyelamatkan anak saat mereka gagal (Muzdalifah, 2014).

Pemberian pujian sangat baik bagi perkembangan anak. Hal ini sebagaimana penelitian Jazilatur Rohma yang berkesimpulan bahwa terdapat pengaruh yang signifikan mengenai pemberian pujian terhadap anak. Dalam penelitiannya, secara kuantitatif hal itu ditunjukkan dengan adanya nilai > yaitu $3.04>1.686$ dan nilai signifikan variable constant yang lebih kecil dari nilai probabilitas $0.004<0.005$. Secara kualitatif hal tersebut menunjukkan bahwa pujian terhadap anak akan menjadikan sesuatu yang positif dalam proses kepercayaan dirinya. Pujian akan menjadi motivasi bagi anak sehingga dia akan lebih berani, tidak minder dan terhindar dari takut akan kegagalan. Pujian sebenarnya juga merupakan hak anak untuk kebutuhan dasarnya yang memang sepatutnya diberikan oleh orang tuanya (Rohma, 2018).

Kemudian untuk mempertahankan jiwa positif anak, hendaknya orang tua bersikap santun terhadap anak. Santun dalam berbicara berarti rukun dan hormat atau menghargai terhadap anak. Hal itu merujuk pada keseimbangan hak dan kewajiabn yang harus dilakukan oleh orang tua kepadanya, terlebih mengenai kewajiban perlindungan psikis anak. Bahasa yang diterima anak akan membentuk prilakunya, dengan bahasa yang santun yang diterimanya setiap hari, secara tidak langsung hal itu akan masuk pada alam bawah sadar ana, kemudian anak akan membiasakan dirinya untuk tumbuh sebagai pribadi yang santun dan ramah dalam menjalani aktivitas sehari-harinya (Zuhrudin, 2017).

\section{Kesimpulan}

Kekerasan verbal pada anak merupakan kekerasan berupa kata-kata seperti menghina, melampiaskan kesalahan dan sebagainya. Banyak dampak buruk dari kekerasan ini, salah satunya ialah menjadikan anak tidak percaya diri, minder bahkan depresi. Langkah-langkah yang bisa dilakukan oleh orang tua untuk melakukan treatment adalah dengan sadar bahwa anak tidak bisa melakukan segala hal dan sempurna dalam segala bidang, membiarkan anak untuk berbicara dari hati ke hati, memeluknya, meminta maaf atas apa yang dilakukannya kemudian membiarkan emosi-emosi kekecewaan bawah sadar anak tereduksi. Setelah emosi bawah sadar anak mengenai dampak verbal abuse yang dialaminya tereduksi, orang tua harus bisa membangun 
kembali dampak-dampak akibat dari verbal abuse yang dialami anak, salah satunya adalah dengan memberikan banyak pujian dan bersikap santun dan menghargai kepada anak.

\section{DAFTAR PUSTAKA}

Basri, Hasan. (1995). Keluarga Sakinah Tinjauan Psikologi Agama. Yogyakarta: Pustaka Belajar.

Vega, De A., Hapidin, H., \& Karnadi, K. (2019). Pengaruh Pola Asuh dan Kekerasan Verbal terhadap Kepercayaan Diri (Self-Confidence). Jurnal Obsesi: Jurnal Pendidikan Anak Usia Dini, 3(2), 433-439.

Hurlock, Elizabeth B. (1993). Perkembangan Anak. Jakarta: Penerbit Erlangga.

Huraerah, Abu. (2018). Kekerasan Terhadap Anak. Bandung: Nusa Cendekia.

Indrayanti, Novi dan Livana PH. (2019). Gambaran Verbal Abuse Orangtua pada Anak Usia Sekolah, Jurnal Ilmu Keperawatan Anak, 2(1), 9-18.

Kurniasari, A. (2019). Dampak Kekerasan Pada Kepribadian Anak. Sosio Informa, 5(1).

Mamesah, Angle. Rompas, Sefti. Katuuk, Mario. (2018). Hubungan Verbal Abuse Orang Tua Dengan Perkembangan Kognitif Pada Anak Usia Sekolah di SD Inpres Tempok Kecamatan Tompaso, e-journal Keperawatan (e-Kp), 6(2), 1-6.

Mahmud, Bonita. (2019). Kekerasan Verbal Pada Anak, An-Nisa', 12 (2), 689694.

Rahman, M. M. (2013). Peran Orang Tua Dalam Membangun Kepercayaan Diri Pada Anak Usia Dini. Edukasia: Jurnal Penelitian Pendidikan Islam, 8(2).

Nazhifah, (2017). Pengaruh Verbal Abuse, Kualitas Komunikasi Orang Tua dan Konformitas Teman Sebaya Terhadap Perilaku Agresif Remaja, Jurnal Ilmu Komunikasi, 15 (3), 262-274.

Sari, S. P. (2014). Hubungan Verbal Bullying Dengan Kecerdasan Interpersonal Siswa Sd Negeri 104206 Sei Rotan Tahun Ajaran 2013/2014 (Doctoral dissertation, UNIMED).

Purwanti, Sumy Hastry. (2017). Kekerasan Pada Anak dan Wanita. Jakarta: Rayyana Komunikasindo. 
Putri, Annora Mentari dan Santoso, Agus. (2012). Persepsi Orang Tua Tentang Kekerasan Verbal Pada Anak, L Nursing Studies, 1 (1), 22-29.

Rohma, Jazilatur. (2018). Pembentukan Kepercayaan Diri Anak Melalui Pujian. Martabat, 2 (1), 117-133.

Salami, S. (2017). Ibu Sebagai Hypnotist Terhebat Di Dunia. Bunayya: Jurnal Pendidikan Anak, 1(2), 1-19.

Santosa, Zen. (2019). Mengenali Kekerasan Pada Anak, Yogyakarta: Alaf Media.

Sugijokanto, Suzie. (2014). Cegah Kekerasan Pada Anak. Jakarta: Kompas Gramedia.

Zuhruddin, Achmad. (2017). Reformulasi Bahasa Santun Sebagai Upaya Melawan Kekerasan Verbal Terhadap Anak, SAWWA, 12 (2), 265-276. 